\title{
Topological Model of Selected Cadastral Structures Visualized in Form of Graphs
}

Summary: The collection of cadastral data is basic spatial data on the basis of which processes associated with land management are conducted. In these activities, it is important that the cadastral structures are in the mathematical-topological model. Such works were being done on the basis of existing geometric data sets and selected sets of attributes. The aim of the present publication was created during these works, concerning the assessment of topological structures of the selected object. The research was associated with the records of neighborhood relationships of selected cadastral objects in the graph model. The graph model of cadastral structures enables the visual assessment of parcel fragmentation. The topological model of these structures is heterogeneous; therefore, it is difficult to clearly and analytically evaluate the sets. The results showed diversity in the structure of the cadastral road parcels. The model was created in the graph database. The results enabled us to find places with a particularly high fragmentation of road parcels. These are places that have arisen in the process of creating roads or their modernization - widening. The conclusions from the research indicate the need of merging parcels owned by municipalities, counties, provinces, or the Treasury (Directorate for National Roads and Motorways). An analysis of cadastral data sets in other Polish regions based on the data visualized in Geopotrals confirms the existence of unjustified parcel fragmentation in areas of newly built roads. The existing situation forces us to search for the causes for the occurrence of such fragmentation and seek solutions to organize them. Our final conclusions indicate the need to perform mergers in these parcels. After arranging these structures, it is easier to interpret the results of a spatial analysis based on the underlying cadastral data; also, a cadastral map would be clearer.

Keywords: graph topological models, cadastral structures, graph

* AGH University of Science and Technology, Faculty of Geology, Geophysics and Environmental Protection, Department of Geoinformatics and Applied Computer Science, Krakow, Poland

** The University of Warmia and Mazury in Olsztyn, Faculty of Geodesy, Geospatial and Civil Engineering, Olsztyn, Poland 


\section{Introduction}

Digital cadastral data stets constitute the basis of spatial information systems. Based on these, tax systems are built $[3,24]$ and a cadastre of real estate $[2,16]$ the taxation of real estate [1], and other thematic systems designed to support space management are also created. Based on these, a spatial analysis supporting the decision-making processes is made.

Models of cadastral data have been the subject of many studies. The result of the work of international scientific teams is an approved model ISO 19152 [12], allowing for the unification of cadastral data models. In addition to this basic research, a lot of works are associated with the analysis of existing cadastral systems [4] in a search for methods to fulfill requirements aimed at meeting the requirements adopted in the ISO LADM standard.

In the data model, the LADM standard evokes spatial data whose relations (topology) are verified on the basis of the rules from the ISO 19125 [14] standard as well as in the space diagram contained in the ISO 19107 standard [13]. The topology of spatial data is closely related to the geometry (Figs. 1, 2). Both of the listed pictures show a similarity between the geometry and topology structures. This enables us to control the accuracy of the recording of geometric data. Also, the important role of topology discloses primarily in the analytical processes. This enables us to process the cadastral data into analytical models. For that purpose, the mathematical-topological model has been built based on the geometric data. Tools of GIS systems use it in analytical processes, inputting into the calculation algorithms.

Topologies can also be stored by using graphs. These structures originate from graph theory (discrete mathematics). Storage is accomplished by using matrixes and data structure and is represented by basic items such as nodes and edges. This can be shown in graph databases Neo4J [21] and Sparskee [23].

a)

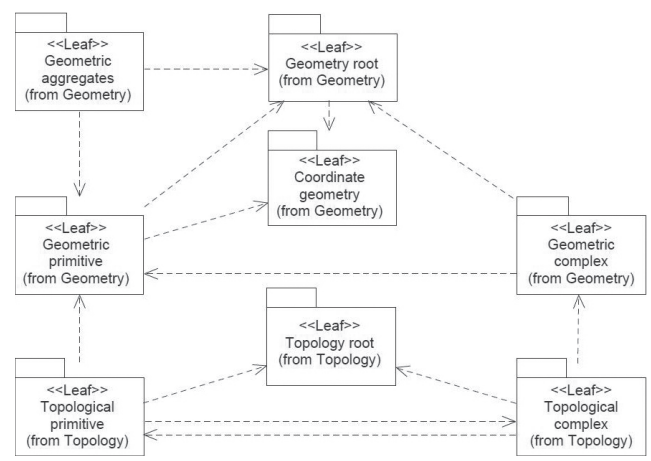

b)

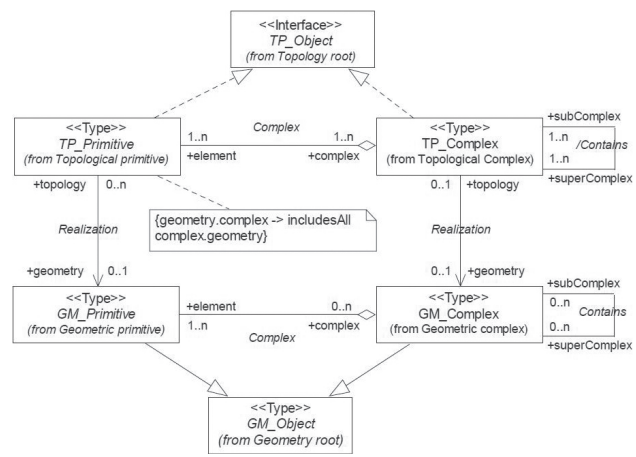

Fig. 1. Relationship between geometry (a) and topology (b)

Source: ISO 19107 [13] 
These databases are considered to be NoSQL databases, and their model is based on graph theory. Database Neo4j enables the processing of graphs to new forms: paths, cycles, trees, and spanning trees $[15,17,24]$. Thus, it is possible to process the topology to new forms that disclose the structure of topological data.

a)

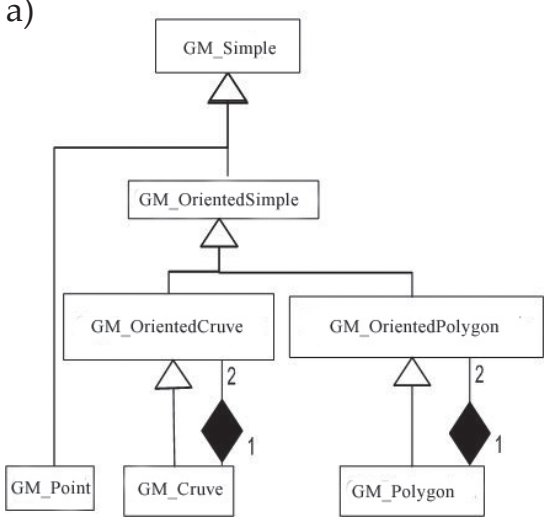

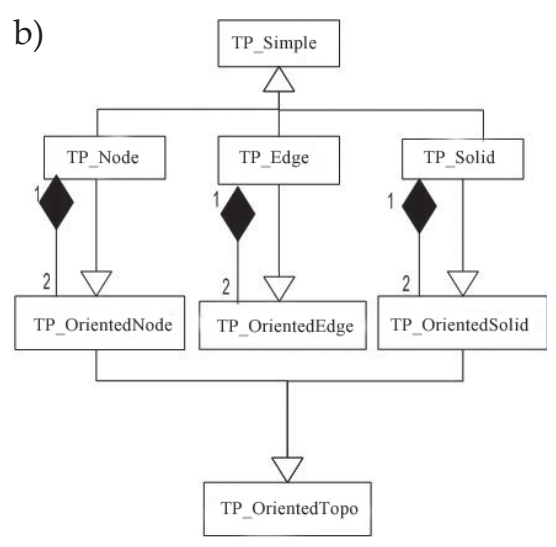

Fig. 2. Simple objects: a) geometric (GM); b) topological (TP)

Source: ISO 19107 [13]

For the purposes of this study, the GIS application and Neo4j graph database were used. The application integration with graph system ArcGIS enables the visualization of cadastral structures in these two platforms [20]. This visualised via ArcGIS using geometric graph exported from Neo4j [15, 24].

In this publication, the goal was a topological assessment of cadastral structures based on data of the selected object - a rural municipality (Giżycko). The results, which are presented in the form of graphs, visualize relationships - topologies. After the presentation of results in the graph and GIS applications, a verification of the received mathematical models was made, and conclusions were formed.

The graph presentations show cadastral structures [18-20], especially for neighborhood parcels. The possibility of selecting components of the graph and its transformation into new forms makes it possible to show the cadastral structure of selected objects (e.g., lane parcels), thus making it possible to assess them.

\section{Methodology of Analysis}

Undertaking the topological evaluation of cadastral structures based on the geometric data of parcels with selected attributes stored in the GIS system required us to adopt a certain methodology of work. This methodology is shown in detail in the diagram in Figure 3. 


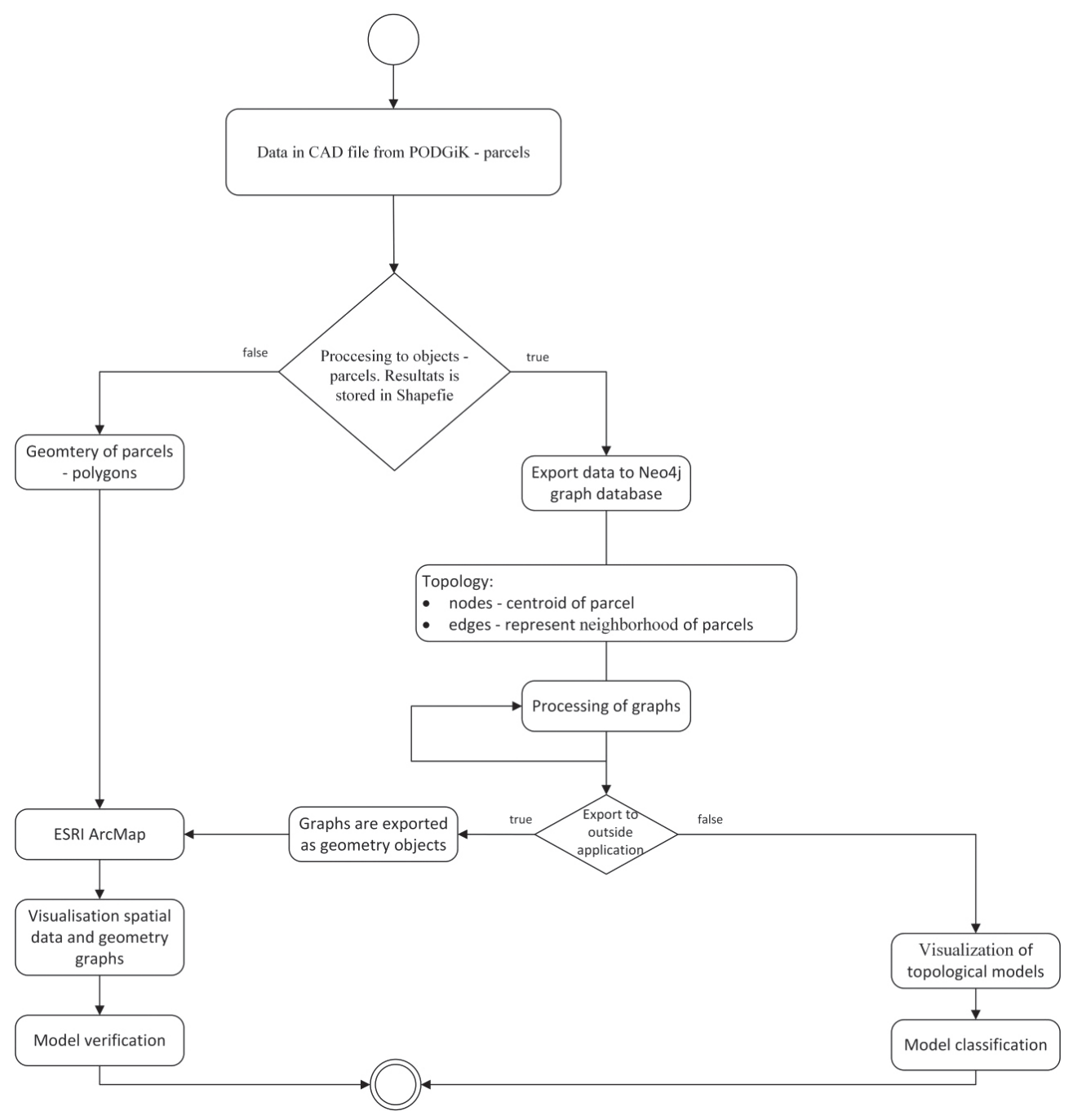

Fig. 3. Methodology adopted in study in two applications: GIS - ArcGIS and graph Neo4j

As noted above, two applications were used for the purposes of this study: GIS (ArcGIS) and graph database Neo4j.

In ArcGIS, the geometric and attribute data of parcels was stored. The graph database stored topological data determined on the basis of geometry. It was assumed that the parcel stored as a geometric object (using a polygon in ArcGIS) and as a topological collection stored in the Neo4j database (identified as a node). Selected attributes of the parcels were assigned to the nodes. The neighborhood of two parcels determined by a common boundary line was disclosed by an edge connecting two nodes. 
Graph platform capabilities are associated with the selection of nodes or edges based on the attributes [23]. These operations are feasible in the Cypher language $[9,22]$. This enables us to obtain new topological models that show the structure of the cadastral data. A visual analysis may indicate a well-organized structure of cadastral data or point to areas that need repair works (e.g., parcel merging).

In the undertaken studies, we decided to select neighborhood parcel relationships. The first involves the disclosure of links between parcels of roadway with neighboring parcels. It was assumed that a presentation in the form of a graph would show structures associated with the availability of roads lanes. The second analysis is related only to the road parcels. The topological model (a graph model) was created based on a model of the road network and neighborhood relationships between road parcels. A detailed analysis of fragments of the graph models enable us to describe, evaluate, and classify the cadastral structures. Based on the created models, it was assumed that the possibility exists to identify those places requiring land consolidation works. The final verification of the results is associated with the import of graphs to the GIS platform. Thus, the graph was visualized in a geometrical form, with cadastral parcels in the background. This form of presentation enables us to verify the results of the analysis made in the graph application. As the result, a form was created to confirm or reject the validity of the indication of places in need of merging works.

\section{Subject of Research}

The subject of our research involved the available cadastral data sets obtained from PODGiK in Giżycko; these show the cadastral parcels of the rural commune (license number: WG.6642.1.187.2016_2806_CL0). The diversified structure of the parcels (Fig. 4) is due to the geographical features of the community related to its many lakes and forests. The agricultural character of the community is disturbed by a large number of recreational parcels in the areas of lakes and forests. Road parcels span a network across the whole investigated area. It is incoherent because of the existing spatial barriers. One of the main barriers is a separated area of municipality. Similar are the areas that are underwater, near railway lines, separated using parcels, divided lanes, and parcel complexes. The diversified cadastral structure of this area was adopted as the object of study. Sets of the output data in the form of cadastral parcels are stored in Shapefile, described with the number and simplified attributes indicating the chosen form of use: road, rail (railway premises), and water (land under flowing and standing waters). Remaining parcels of another form of use were assigned identifying the attribute as "parcel."

As mentioned earlier, the possibility of data manipulation was increased by using the graph database [20]. As the result of introduction studies was made presentation of neighborhood parcels. 
a)

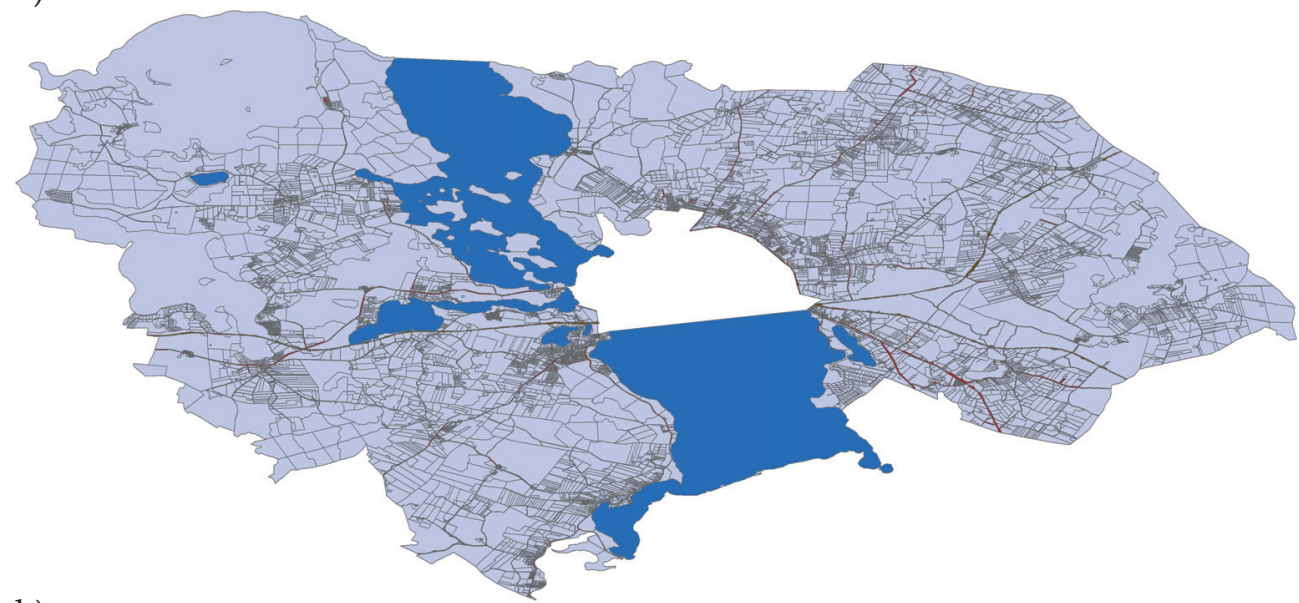

b)

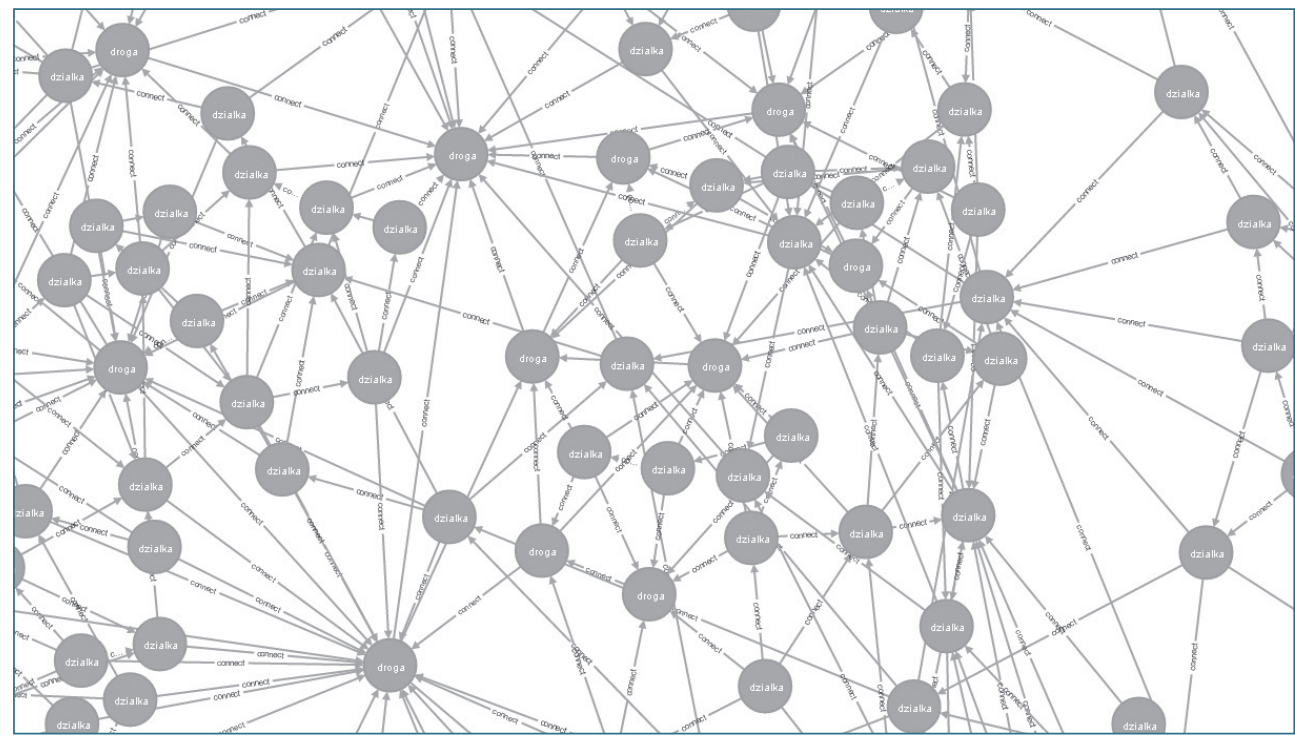

Fig. 4. Area covered by study in geometric and graphic presentation:

a) cadastral map of a rural commune Giżycko in form of GIS; b) fragment of topological data visualized using graph imaging neighborhood of cadastral parcels (developed in the Neo4j database) based on data from cadastral map

Source: [20]

A sample is shown in Figure 5 (graph nodes represent parcels, and lines - graph edge indicate existing neighborhood). The right side of Figure 5a shows a regular structure in which the nodes of two roadway parcels were assigned a bundle of nodes showing numerous parcels. The left side of Figure 5a shows structures that are difficult to interpret unambiguously. They should be explained by verifying the 
a)

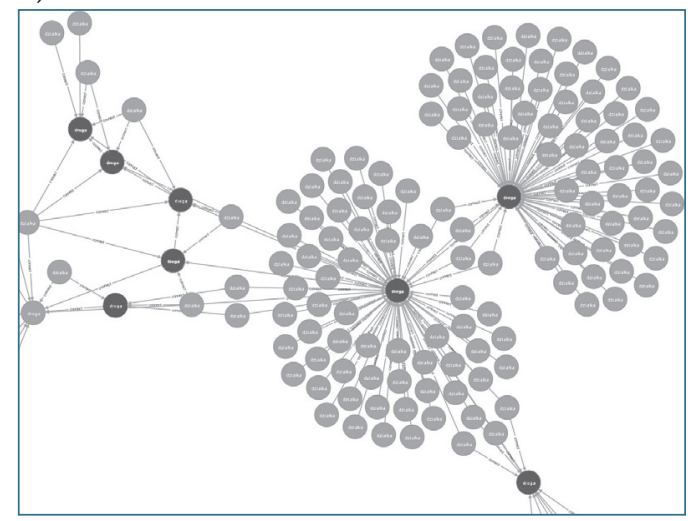

b)

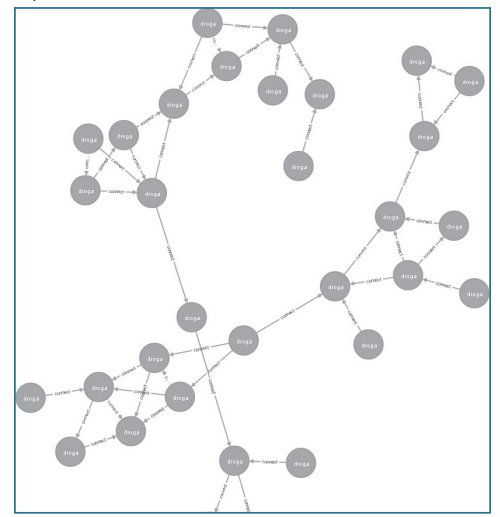

Fig. 5. Diverse structure of parcels - fragment of the graph model imaging neighborhood: a) neighborhood of parcels in relationship to roads (nodes of road parcels distinguished with dark gray color); b) fragment of model showing the neighborhood of road parcels presented in form of inconsistent graph

Source: [20]

results with the cadastral map. Likewise, the graph shown in Figure 5b contains various structures $[15,24]$ of sub-graphs (network planar graphs and non-planar) that should be explained.

\section{Results}

In pursuing the aim of this work with the adopted methodology, the results presented below illustrate various topological structures, showing different relationships between neighboring parcels in the form of graph visualization.

Figure 6 shows a simple cadastral structure illustrating the model of a neighborhood of parcels that constitute access roads to properties. The example in Figure 6a-c corresponds to the graph construction of the network. This storage form is called a tree. This structure is built with elements: root and branches. Branches illustrate the lane parcels on which the access road ends. Figure $7 \mathrm{a}-\mathrm{c}$ shows the detail of the road network with two access routes. This time in the graph, we can see one loop and two branches. Parcels of numbers 3915, 3859, and 3719 form a loop - the bypass of a parcel complex. Parcels of numbers 3818 and 9964 are the access roads to the properties that do not allow further travel. The structure is clear - it is called a star structure.

Figure 8 shows the structure recorded in the form of a planar graph, and in Figure 9 - a non-planar graph. The planar graph indicates that the roadway parcels form an interrelated coherent road network with numerous loops. On the other hand, the non-planar graph [24] points to some special cases. They can result from a geometric mistake; e.g., overlapping parcels or the lack of regular structure (like when the parcels are concave figures). Puzzling is the fact that some road parcels 
on the graph model shown in Figure 8 have no adjacent parcels assigned. This situation indicates an impaired structure. The verification of these results on the GIS map shows a large fragmentation of the roadway parcels, therefore explaining the situation. The fragmentation of the road parcels makes the graph model heterogeneous.

a)

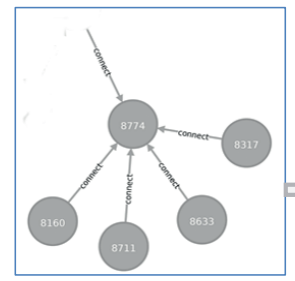

b)

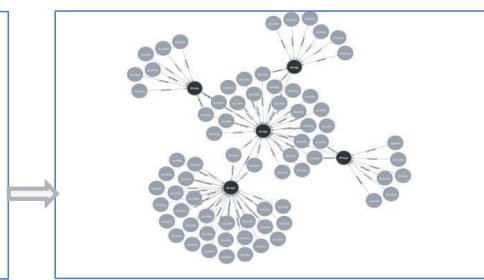

c)

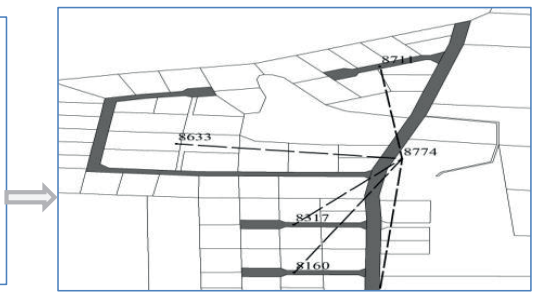

Fig. 6. Graph presentation showing structure of cadastral divisions: a) graph of neighborhood of road parcels; b) graph of neighborhood of parcels to road parcels; c) verification of results on GIS map (Network model shaped like a tree)

a)

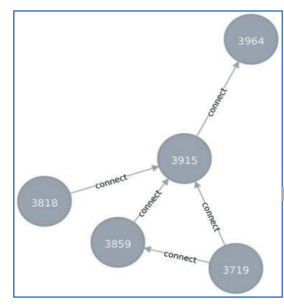

b)

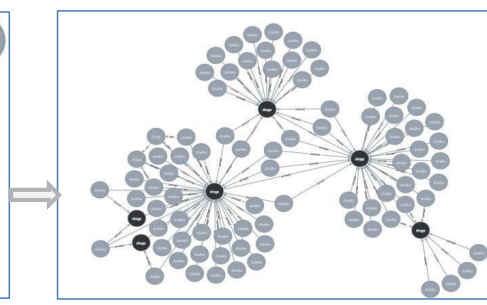

c)

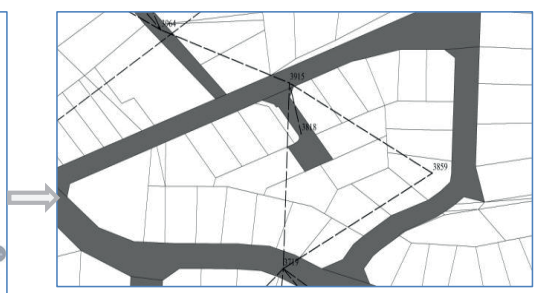

Fig. 7. Graph presentation showing structure of a cadastral divisions: a) graph of neighborhood of road parcels; b) graph of neighborhood of parcels to road parcels; c) verification of results on GIS map (Network model with loops)

a)

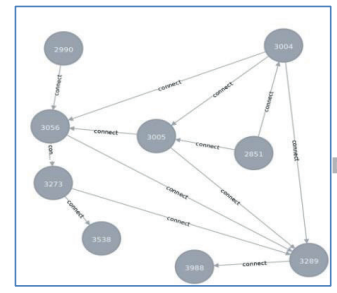

b)

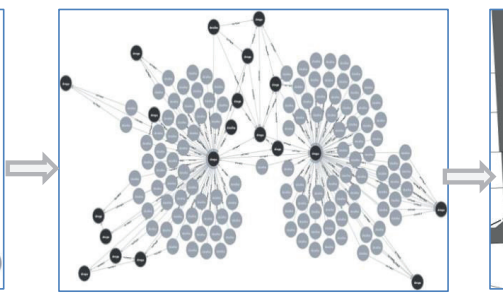

c)

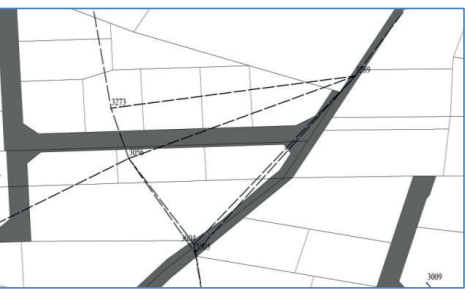

Fig. 8. Presentation of graphs illustrating structure of division of cadastral parcels when there is significant fragmentation of road parcels: a) graph of neighborhood of roadway parcels; b) graph of neighborhood of parcels to road parcels; c) verification of results on GIS map (Network model with loops. Planar graph) 
a)

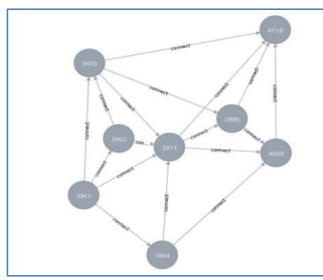

b)

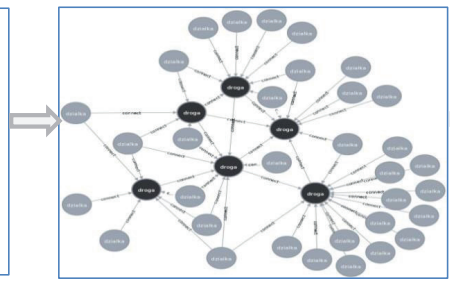

c)

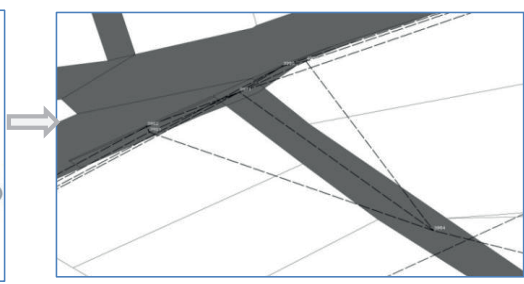

Fig. 9. Presentation of graphs illustrating structure of division of cadastral parcels when there is significant fragmentation of road parcels: a) graph of neighborhood of road parcels;

b) graph of neighborhood of parcels to road parcels; c) verification of results on GIS map

(Network model with loops. Non-planar graph)

The results of the analyses, presented in the form of selected parts of graphs illustrating the vicinity of selected cadastral parcels, point to various forms of cadastral structures. This is associated with the existing division resulting from the different forms of land use. Alongside that, it was noted that the results depend on the quality of the input data. If the cadastral data is unstructured (e.g., a large fragmentation of parcels occurs within a road lane), the topological model is heterogeneous. Thereby, any analytical processes carried out on such data would be difficult, and the results would be ambiguous and difficult to interpret.

\section{Conclusions}

The geometrical and topological data consists of mutually reinforcing sets of spatial data. In studies, often only geometry sets are used, with topological data is stored in analytical structures. Linking the GIS platform with the graph platform enables us to process the topological data and visualize it in the form of graphs. A visual analysis of the graph models enables us to assess the existing cadastral structures. The diversified results on subsets of the data from the examined object point to a large variety of structures. Places of harmonious structure of the neighborhood can also be shown, as well as those in which the interpretation of the results is very difficult. In particular, the large fragmentation of lane parcels prevents an unambiguous interpretation of the results.

Assuming that the cadastre should be a basic set of reference for a spatial analysis supporting decision-making processes [18], care should be taken to organize the structures through consolidation. As shown by the results, a consolidation of the road cadastral parcels is necessary. A basic analysis based on graph algorithms (trees, paths...) and performed on unstructured sets create results that are difficult to interpret unambiguously. With organized geometrical structures, results from analytical processes give us hope to achieve a purpose in the research. 
A review and analysis of the cadastral sets visualized in Geopotrals in other Poland regions confirms the existence of the unjustified fragmentation of parcels, especially in the areas of newly constructed or upgraded roads. The presented fragmentation (Fig. 10a-c) should occur only temporarily during the process of division and expropriation; however, it is not like this. The existing situation forces us to ensure the procedures related to the unbundling of parcels for public purposes. References to the need of merging unbundled parcels into one public property should be included in the procedures for these types of works. There is a need to conduct mergers in these areas. Good practices for merging road parcels are presented in Figure 10d-f.

a)

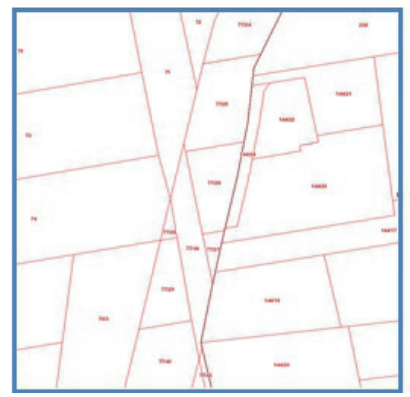

b)

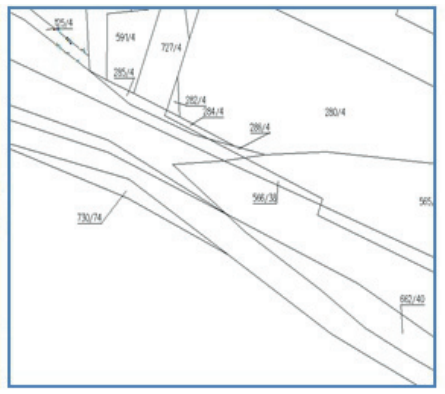

e)

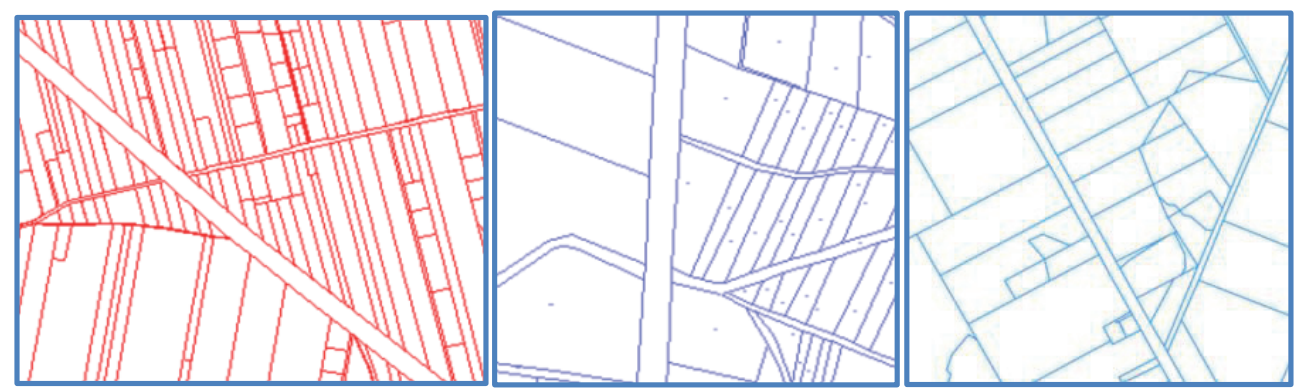

c)

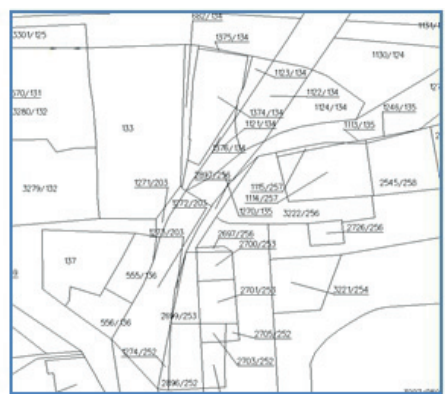

f)

Fig. 10. Examples of fragmentation of road parcels $(a, b, c)$ and ordered structures $(d, e, f)$ : a) Łódź province]; b), c) Dolnośląskie province - Siemianowice Śląskie; d) Radom province; e) Torun province - Lipno; f) Poznań province, district Lubliniec Source: a) [8], b), c) [5], d) [7], e) [11], f) [6]

After arranging the structures of cadastral roadways, an interpretation of the spatial analyses based on the underlying cadastral collections is simpler. This raises hope that the cadastral map is easier to read and corresponds to the hierarchy of road parcels, depending on the class of the road. 


\section{References}

[1] Ciak J., Wąsewicz B.: Kataster jako warunek reformy systemu opodatkowania nieruchomości w Polsce. Prawo Budowlane Państwa i Samorządu, 2014, [on-line:] DOI: http://dx.doi.org/10.12775/PBPS.2014.035 [access: 11.07.2016].

[2] Ciak J., Wąsewicz B.: Oczekiwany model katastru nieruchomości w Polsce. Prawo Budżetowe Państwa i Samorządu, nr 1(3), 2015, pp. 27-43.

[3] Dawid L.: Problemy z wykorzystaniem danych z katastru nieruchomości do celów podatkowych na przykładzie gminy wiejskiej Będzino. Infrastruktura i Ekologia Terenów Wiejskich, nr 1/III, 2012, pp. 7-17.

[4] Gatta G., Arioti E., Gabriele Bitelli G.: Geomatics science applied to cartographic heritage and archive sources: A new way to explore the XIX th century Gregorian Cadastre of Bologna (Italy), an ante-litteram 3D GIS. Journal of Cultural Heritage, [on-line:] http://www.sciencedirect.com/science/article/pii/ S1296207416301042 [access: 20.08.2016].

[5] Geoportal miasta Siemianowice Śląskie [on-line:] http://siemianowice.geoportal2.pl/map/www/mapa.php?CFGF=wms\&mylayers=+granice+ [access: 20.09.2016].

[6] Geopotral powiatu Lubiniec [on-line:] http://www.lubliniec.giportal.pl/ [access: 20.09.2016].

[7] Geoportal powiatu Radomskiego, [on-line:] http://mapy.geoportal.gov. $\mathrm{pl} / \mathrm{imap} /$ ?gpmap=gp0\&actions=acShowServices_KATASTER [access: 20.09.2016].

[8] Geoportal województwa łódzkiego), [on-line:] http://geoportal.lodzkie.pl/ imap/ [access: 20.09.2016].

[9] Holzschuher F., René P.: Performance of graph query languages: comparison of Cypher, Gremlin and native access in Neo4j. [in:] 16 $6^{\text {th }}$ International Conference on Extending Database Technology, EDBT' 13, ACM Press, New York 2013, pp. 195-204, DOI:10.1145/2457317.2457351.

[10] Hycner R.: Podstawy katastru. Uczelniane Wydawnictwa Naukowo-Dydaktyczne AGH, Kraków 2004.

[11] Informacja katastralna powiatu lipnowskiego, [on-line:] http://lipno. geoportal2.pl/map/www/mapa.php?CFGF=wms\&mylayers=+granice+OSM+ [access: 20.09.2016].

[12] ISO 19152:2012: Geographic information - Land Administration Domain Model (LADM).

[13] ISO 19107:2004: Geographic information - Spatial schema.

[14] ISO 19125:2004: Geographic information - Simple feature access.

[15] Kulikowski J.L.: Zarys teorii grafów. Państwowe Wydawnictwo Naukowe, Warszawa 1986.

[16] Kuryj J., Wiśniewski R., Źróbek R.: Gospodarka nieruchomościami. Wydawnictwo Uniwersytetu Warmińsko-Mazurskiego, Olsztyn 2000. 
[17] Lewandowicz E.: Przestrzeń geograficzna jako przestrzeń topologiczna. [in:] Modelowanie informacji geograficznej wedtug norm europejskich i potrzeb infrastruktur informacji geograficznej: materiaty $V$ Ogólnopolskiego Seminarium z cyklu Modelowanie Informacji Geograficznej, Warszawa, 30 marca 2007 r., Instytut Geodezji i Kartografii, Warszawa 2007, pp. 27-37.

[18] Lewandowicz E.: Drzewa grafowe w analizach dostępności. Archiwum Fotogrametrii, Kartografii i Teledetekcji, Kraków, vol. 19, 2009, pp. 269-277.

[19] Lewandowicz E.: Algebraic transformations of cadastral topological data. Journal of Applied Geodesy, vol. 5, issue 3-4, 2011, pp. 117-185.

[20] Lisowski P., Lewandowicz E.: Przetwarzanie i wizualizacje zapisów twa danych katastralnych w strukturach grafowych. Roczniki Geomatyki, t. 14, z. 4 (74), 2016, pp. 487-496, [on-line:] http://rg.ptip.org.pl/index.php/rg/article/view/ RG2016-4-LisowskiLewandowicz/1650 [access: 11.07.2016].

[21] Neo4j Manual, [on-line:] http://neo4j.com/docs/stable/ [access: 11.07.2016].

[22] Płuciennik-Psota E., Płuciennik T.: Using Graph Database in Spatial Data Generation. [in:] Man-Machine Interactions 3, Advances in Intelligent Systems and Computing, 242, Springer International Publishing, 2014, pp. 649-658, doi:10.1007/978-3-319-02309-0.

[23] Sparsity-Technologies, [on-line:] http://sparsity-technologies.com/ [access: 11.07.2016].

[24] Wilson R.: Wprowadzenie do teorii grafów. Wydawnictwo Naukowe PWN, Warszawa 2000.

\section{Topologiczny model wybranych struktur katastralnych wraz z wizualizacją $\mathrm{w}$ postaci grafów}

Streszczenie: Zbiór danych katastralnych stanowi bazowe dane przestrzenne, na których opierają się procesy związane z zarządzaniem gruntami. Jest on także istotnym rejestrem, na podstawie którego prowadzi się analizy przestrzenne w procesach decyzyjnych. W tych działaniach ważny jest zapis struktur katastralnych w modelu matematyczno-topologicznym. Podjęto się takich prac na podstawie istniejących zbiorów danych, głównie geometrycznych i wybranych zbiorów atrybutów. Przy realizacji tego zadania wykreował się cel niniejszej publikacji związany z oceną topologiczną struktur katastralnych wybranego obiektu badawczego. Badania wiązały się z zapisem relacji sąsiedztwa wybranych obiektów katastralnych w modelu grafowym. Grafowy model struktur katastralnych pozwala na ocenę wizualną rozdrobnienia działek. Model topologiczny tych struktur jest niejednorodny i utrudnia jednoznaczną ocenę analityczną zbiorów. Wyniki wykazały różnorodność w strukturze działek ewidencyjnych pasów drogowych. Model stworzono w grafowej bazie danych. Wyniki pozwalają na znalezienie miejsc o szczególnym rozdrobnieniu działek 
pasa drogowego. Są to miejsca, które powstały w procesach tworzenia pasów drogowych lub ich modernizacji - poszerzania. Wnioski z wykonanych badań wskazują na konieczność scaleń działek, których właścicielami są gminy, powiaty, województwa czy Skarb Państwa (Dyrekcja Dróg Krajowych i Autostrad). Analiza zbiorów katastralnych w innych regionach kraju, w oparciu o dane wizualizowane w Geopotralu, potwierdza istnienie nieuzasadnionego rozdrobienia działek na terenach nowo wybudowanych ciągów komunikacyjnych. Istniejąca sytuacja zmusza do poszukiwań przyczyn zaistnienia takiego rozdrobienia i szukania rozwiązań w celu ich uporządkowania. Wnioski końcowe wskazują na konieczność przeprowadzania scaleń w tych obszarach. Po uporządkowaniu tych struktur prostsza będzie interpretacja wyników analiz przestrzennych, opartych o bazowe zbiory katastralne, a także obraz mapy katastralnej będzie czytelniejszy.

\section{Słowa}

kluczowe: grafowe modele topologiczne, struktury katastralne, graf 